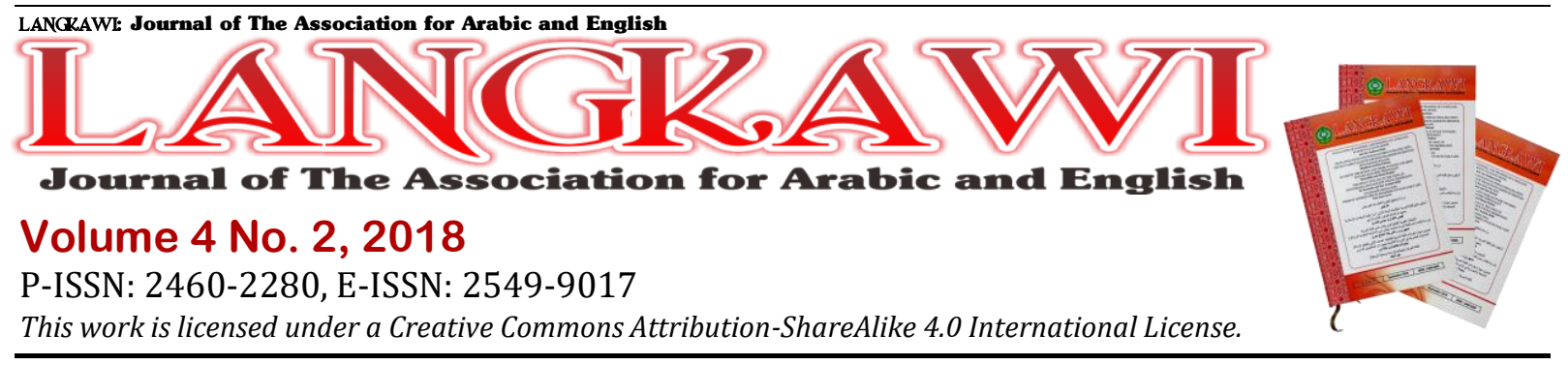

\title{
Constructing WH-Questions through An Error Analysis at Junior High School of Indonesia
}

\author{
Masruddin Masruddin ${ }^{1}$ Karmila Karmila ${ }^{2}$ \\ 1'Institut Agama Islam Negeri Palopo, Indonesia. E-mail: anthosmithstain@yahoo.com \\ 2Institut Agama Islam Negeri Palopo, Indonesia. E-mail: karmila@iainpalopo.ac.id
}

\begin{tabular}{l} 
ARTICLE INFO \\
\hline Keywords: \\
Error analysis; WH- \\
Questions; descriptive \\
research \\
How to cite: \\
Masruddin, M., (2018). \\
An Error Analysis in \\
Constructing WH- \\
Questions; A Case Study \\
at Junior High School, \\
4(2), 123-137. \\
DOI: \\
http://dx.doi.org/10.31332/ \\
lkw.v4i2.852
\end{tabular}

\begin{abstract}
This research aims at finding out the types of errors committed by the students in making wh- questions. The researcher applies descriptive research. It is used to describe the errors of the students in making wh-questions. The population of this research is the second year students of SMP Negeri 2 Bua Ponrang, South Sulawesi, Indonesia. The total number of population in this research is 240 students. The researcher uses purposive sampling technique in determining class VIII A. Therefore, the total number of sample in this research is 28 students. Based on the result of data analysis, the researcher concludes the types of error that the second year students at SMP Negeri 2 Bua Ponrang committed to making wh-questions are an omission, simple addition, archi-form, alternating form, misordering, and misselection. The omission is dominant errors that the students made because from 1017 of total errors, 475 or $46.7 \%$ of the total errors are an omission. Then, it followed by archi-form with the total errors is 275 or $28 \%, 155$ errors of simple addition or $15.2 \%, 93$ errors of misordering or 9.1\%, 11 errors of alternating form or 1.1\%, and the least types of errors is misselection with eight errors or $0.8 \%$.
\end{abstract}

\section{Introduction}

Gunning (2010) states that "question can be used to develop concepts, build background, clarify reasoning processes, and even lead students to higher levels of thinking." Stazny (2005) implies that questions have some didactic functions. In the higher cognitive level, it can be functioned to ask students' response about knowing that they previously learned, to ask them recalling factual information, to check or test the students about information, and to seek more information from the teachers by them. Therefore, the students can get the information they need from the teacher by using the question, and the teacher can get information that needed by the students.

Since the question has different types, it also has different functions and structures in both English language and Indonesian language. According to Greenbaum (2006), there are two majors of interrogatives, they are: yes/no questions and wh-questions, "yes/no questions are generally intended to elicit the reply yes or no. Wh-questions expect a reply that supplies the information that the wh-word indicates as required. They are called wh-questions because the wh-words generally begin with wh-, the exception being how. For the objective in gaining more detail 
information wh-questions is more likely to be used rather than yes/no questions. Nevertheless, wh-questions have more complicated structure than the structure of yes/no questions.

There are some distinctions between wh-question sentences in English and Indonesian. First, the kinds of question words for asking about people, in English there are who, whose, and whom while in Indonesian the question word which used is the only Siapa, whether the question asks about the subject, the object, or possession. Second, there is no auxiliary in the Indonesian language. In making wh-question, there is a helping verb (auxiliary) inversion. Since the Indonesian language does not have, learners might be distracted to use does or is and do or are as the helping verb.

Moreover, third, Indonesian language does not have tenses in describing time as English does. The tenses are related to the helping verb used in the wh-question; therefore, it also becomes a problem for the students. Those distinctions might be a trigger for students to make errors in making wh question.

Before conducting the research, the researcher found that the students of SMP Negeri 2 Bua Ponrang make an error in their writing about constructing WHQuestion. WH-Question is important structures for ESL/EFL students because they learn how to communicate using questions and also understand how helpful questions are to find out information. WH-Question used in social interaction such as: asking for information about something (what is your name?), asking for repetition or confirmation (What? I can't hear you. You did what?), asking in or at what place or position (Where do they live?) and so forth.

Based on the importance of wh-questions in gaining information, and the distinctions between English and Indonesian structures which are explained above, the researcher is interested in research "An Error Analysis in Constructing WHQuestions: A Case Study at the Second Year Students of SMP Negeri 2 Bua Ponrang."

The scope of the research is the students' errors in constructing wh-question. To make the study focus, the researcher makes limitation for the tenses which are used in this research, which is simple present tense. The question words those are used in this research are: what (for asking thing), where (for asking place), when (for asking time), why (for asking reason), who (for asking people as subject), and how (for asking ways). The types of error in this research is from Dulay et al. theory; they are an omission, simple addition, archi-form, alternating form, misordering, and misselection.

There have been some researchers carried out research related to the students' errors in constructing wh-questions: (1) Irfaniah (2014) in her research entitled "An Error Analysis in Making WH-Questions (A Case Study of the Second Year Students of SMP Islam Al-Syukro Universal", found out that there were 268 errors made by the students. Sixty errors or $22.4 \%$ are the omissions of helping verb, 52 errors or 19.4 $\%$ are archi-form of helping verb, 55 errors or $20.5 \%$ are archi-form of the verb, 79 errors or $29.5 \%$ are archi-form of question word, and 22 errors or $8.2 \%$ are misordering of helping verb. Those errors are caused by interlingual transfer and intralingual transfer. Based on the results, it can be concluded that the ability of the students in making wh-questions was still low. Sari (2013) in her research entitled "An Analysis of Students' Errors in Constructing Wh-Questions Made by the Eighth Grade of SMPN 1 Gunung Jati", found out that the students put WH-Question in the 
middle sentence, not at the beginning of the sentences and some students knew placement of WH-Question but they did not understand about grammar. The percentages of students' errors in constructing WH-Question in the simple present tense. The percentage of the error is $38.81 \%$. Based on the percentages of the students' errors, it means that the percentage of the students' errors in the construction of WH-Question made by students of the eighth grade of SMP Negeri 1 Gunung Jati are still lacking. Friedmann (2010) in his journal entitled "Question Production in Agrammatism: The Tree Pruning Hypothesis," found out that Hebrew- and Arabic- speaking agrammatics encounter severe difficulties in Whquestion production but retain the ability to produce yes/no questions. Englishspeaking agrammatics do not show this dissociation and can form neither Wh- nor yes/no questions. These dissociations, as well as the error pattern, are explained by reference to the Tree Pruning Hypothesis, according to which the highest nodes of the syntactic tree, which are required for Wh-questions in Hebrew, Arabic and English, and for yes/no questions in English, are inaccessible in agrammatism.

The similarity between the previous studies above and this research is that focusing on wh-questions. All of the previous studies above focused on all of the types of question words (who, whom, whose, what, which, where, when, why, and how), but the researcher is more interested to focus on five question words, they are: what, where, when, why, who, and how. This study is a case study at SMP Bua; this can be an excellent contribution to the condition of a student in Indonesia especially in South Sulawesi.

Purpose of the study is "to find out the type of errors made by the second year students at SMP Negeri 2 Bua Ponrang in constructing wh questions. It is expected to have a contribution to the theory of error analysis practice."

\subsection{Literature Review}

\section{The Concept of Error Analysis}

a. Understanding of Mistakes and Errors

Harmer (2007) stated that errors are mistakes which they cannot correct themselves and which therefore need explanation. Whereas, mistakes occur whenever students produce language that is not correct. Masruddin (2010) stated that when we talk about the error, we also think about the error. As for mistakes, they usually result from performance deficiency.

According to LeTourneau (2010), "mistake is a random or accidental deviation from what one intends to do; an error is a systematic deviation from what one intends to do." Richards (2005) states that learner makes a mistake when writing or speaking because of lack of attention, fatigue, carelessness, or some other aspects of performance. Whereas, an error is the use of the exact item in a way that a fluent or native speaker of the language regards it as showing faulty or incomplete learning. In other words, an error occurs because the learner does not know what is correct, and thus it cannot be self-corrected. Brown (2007) states that "a mistake refers to a performance error that is either a random guess or a "slip" in that is a failure to utilize a known system correctly. Mistakes, when attention called to them, can be self-corrected. An error is a noticeable deviation from the adult grammar of a native speaker, reflects the competence of the learner. It cannot be self-corrected". James 
(2010) defines error in a very loose way as an "unsuccessful bit of language." Additionally, according to Dulay et al., (2010), failure is the flawed side of learner speech or writing. It is part of conversation or composition that deviates from some selected norm of mature language performance.

First language or mother tongue is not the same with a second language or English. Learning mother tongue is not influenced by another language, but their mother tongue influences it as the first language for them. It causes an error and mistake happen in learning English. 'Second language learning is a process that is not unlike first language learning in its trial and error nature. Learners make mistakes in the process of acquisition, and that process will be impeded if they do not commit errors and then benefit from various forms of feedback on those errors' (Aziz, 2011).

From the statements above, it can be concluded that a mistake is a deviation that is made accidentally caused by some aspect of performances and can be selfcorrected, while the error is a systematic deviation in language performance caused by the incompetence of learners to perform the language, and it cannot be selfcorrected.

b. Types of Error

According to Dulay et al., (2010), there are four types of errors; they are omission, addition, misformation and misordering:

1) Omission, characterized by the missing of an item that must appear in a wellstructured utterance. For example:

When the lesson start every day? Omission: does

When does the experience start every day?

2) Addition, characterized by the occurrence of an item must not appear in a wellstructured utterance. There are three types of addition errors: double marking, regularization, and simple addition.

a) Double marking: the presence of certain items which are not required in some linguistic construction, but are necessary for others. As in:

How did he break the vase?

There are two verbs of past tense in the sentence, to make it well structured it should be:

How did he brake the vase?

b) Regularization: the presence of a marker that typically added to a linguistic item, to exceptional linguistic items that do not take a marker. For example: Verb: put-putted Noun: sheep sheeps.

c) Simple addition: the presence of linguistic item other than in a double marking or regularization. For example:

Who are your friend's classmates?

Who are your classmates?

3) Misformation, characterized by the use of the incorrect form of morpheme or structure. There are three types of misformation: regularization, archi-forms, and alternating forms

a) Regularization: are those in which a regular one places an irregular marker, as in singed for sang or mouses for mice. 
b) Archi-forms: the use of one member of a class of forms to represent others in the class. For example:

Whom is the architect of Liberty Statue?

Who is the architect of Liberty Statue?

c) Alternating forms: the use of a various member of a class with each other, it is caused by the development of the learner's vocabulary and grammar.

For example:

Why do all Museum in Jakarta close at Monday?

Why do all Museum in Jakarta close on Monday?

4) Misordering, characterized by a morpheme or group of morphemes which are incorrectly placed in an utterance. For example:

What is your bag color?

What color is your bag?

According to James (2010), errors are categorized into omission, over inclusion, misselection, disorder, and blend:

1) Omission, where some elements of a word are omitted which should be present.

2) Overinclusion, where some element is present which should not be there.

3) Misselection, where the wrong item has been chosen in place of the right one.

4) Disorder, where the elements presented are correct but wrongly sequenced.

5) Blend, where there is not just one clear target, but two.

Based on the classifications above, it can be inferred that errors can be classified into error of omission for the absence of some item, error of addition for some item that should not be there, misformation for form of morpheme or structure that are wrongly used, misselection for some item that wrongly selected, misordering for the elements of utterance that are incorrectly sequenced, and blends for using two forms because of uncertainty in deciding which one is required.

a. Source of Error

According to Cowan (2008), there are four causes of grammatical errors, they are:

1) Performance error: an error made by language learner indicates a process in the act of speaking or writing, and not because the learner ignores the grammatical rules.

2) Imperfect learning: it means that a rule or the restriction that apply to that rule has not internalized by the learner.

3) Overgeneralization: it occurs when a grammar rule is applied to forms that do not take it.

4) Influence of the native language: it occurs when language learners produce language from transferring of grammar rules from their native language.

Meanwhile, Brown (2007), stated that causes of error are:

1) Interlingual transfer

The interlingual transfer is the interference of native language in learning the second language. Before the system of the second language is familiar, the native language is the only previous linguistic system upon which the learner can draw. 
2) Intralingual transfer

The intralingual transfer is manifested when learners have begun to acquire parts of the new system. It makes students start to generalize a rule within the target language.

3) Context of learning

Students often make errors because of the explanation that misleads them. This misleading could be given by teacher, faulty presentation of a structure or word in a textbook, or even because of a pattern that was rotely memorized in a drill but improperly contextualized.

4) Communication strategies

Communication strategies were related to learners ${ }^{e e}$ learning styles. The strategies are produced by the learners become the source of error.

According to explanation above, the sources of error are interlingual transfer that is the influence of the native language in learning second language, intralingual transfer that is imperfectness in learning second language and causes overgeneralization, context of learning that is misleading from learning sources, and communication strategy that is the learning styles of a learner that leads to error.

b. Error Analysis

As what has been discussed in previous sub subchapter, an error is concluded as a systematic deviation in language performance. Meanwhile, the term of error analysis is described in various explanations. James (2010) describes an error analysis is the process of determining the incidence, nature, causes, and consequences of unsuccessful language.

According to Zawahreh (2012), error analysis is an analysis of the linguist error that learner makes. Explanation of errors is considered one of the main important goals of errors analysis, so serious hard attempt was made to explain the plausible cause of the students' errors. They could be attributed to many sources: mother tongue interference, intralingual, interference, teachers, false analogy and the familiarity of the appropriate collections. Analyzing the collected data will indicate the sources of these errors. Then, Gunawan (2015) and Kusumadewi (2017) state that error analysis is an activity to identify, classify and interpreted or describe the errors made by someone in speaking or in writing and it is carried out to obtain information on common difficulties faced by someone in speaking or in writing English sentences.

Meanwhile, Ellis and Barkhuzein (2005) state that "error analysis consists of a set of procedures for identifying, describing, and explaining learner errors." Additionally, Brown (2007) states that "the fact that learners do make errors, and that these errors can be observed, analyzed, and classified to reveal something of the system operating within the learner, led to a surge of the study of learner's errors, called error analysis."

Based on some definitions above, the researcher concludes that error analysis is a procedural method that can be applied in determining the deviation in language performance.

c. The Steps of Error Analysis 
According to Ellis and Barkhuzein (2005) there are five steps in conducting an error analysis, they are:

1) Collection of a sample of learner language

The researcher can collect the sample in two ways: researcher can specify the research question they intend to collect or make it large sample by collecting different learners, different types of language and different conditions of production.

2) Identification of error

The basic procedure in identifying errors is as follows: first, prepare a reconstruction of the sample as learner's native speaker counterpart would have produced this. Then, compare every utterance/sentence produced by the learner with well-formed utterance/sentence constructed by the native speaker. Finally, identify which part(s) of learner's utterance/sentence differs from the native one.

3) Description of error

About (2009) writes the description of errors is essentially a comparative process, the data being the original erroneous utterances and the reconstructed utterance. Description of learner errors involves specifying how the forms produced by the learner differ from those produced by the learner's native speaker counterparts. It focuses on the surface properties of learner utterances. There are two steps:

a) The development of a set of descriptive categories for coding the errors that have been identified.

b) Recording the frequency of the errors in each category.

4) Explanation of error

Explaining errors involves determining their sources to account for why they were made is the most important stage in error analysis. The concern here will be with the psycholinguistic sources of error (i.e., those relating to the processing mechanisms involved in L2 use and to the nature of the L2 knowledge system).

5) Error evaluation

Error evaluation involves determining the gravity of different errors intending to decide which ones should receive instruction. Planning for an error evaluation study involves the following steps:

a) Select the errors to be evaluated.

b) Decide the criterion of which the errors are to be judged. The most commonly chosen criterion is "gravity" (seriousness).

c) Prepare the error evaluation criterion. This will consist of a set of instructions, the erroneous sentences or text, and a method for evaluating the errors.

d) Choose the judges. It is best to have at least two as this increase the reliability and generalize ability of the result.

Based on the explanation earlier, the steps in conducting error analysis begins with collecting the sample, identifying the errors, describing the errors, explaining the errors, and then evaluating the errors based on some criterion.

d. The Significance of Error Analysis

Error analysis has two pedagogical implications, they are:

1) Implications for Foreign Language Teachers 
According to Dulay et al., (2010), "error analysis provides data from which interferences about the nature of the language learning process can be made. It indicates to teachers and curriculum developers which part of the target language students have most difficulty producing correct and which error types detract most from learner's ability to communicate effectively."

Supporting the statement above, Erdogan (2005) states that "by following the students "progress, the teachers can carry on their studies following what the learners need to know and what part of the teaching strategy to chance or reconstruct."

2) Implications for Syllabus Designers

Erdogan (2005) states that "error is significant data for syllabus designers as they show what items are important to be included or which items need to be recycled in the syllabus. Analysis of second language learners' errors can help identify learners' linguistic difficulties and needs at a particular stage of learning. It is essential for a syllabus to provide with the needs for learning appropriately and errors are important evidence for that."

Based on the explanation above, the researcher concludes that error analysis gives benefits to English teachers as it provides information of what errors the learners made most so the teachers can teaching strategy, and to syllabus designer as errors proved what learners' needs in learning the second language.

\section{Method}

The researcher applied descriptive research. This research method was used to describe the errors of the second year students of SMP Negeri 2 Bua Ponrang in constructing wh-questions. The population of this research was the second year students of SMP Negeri 2 Bua Ponrang in academic year 2015/2016. It consisted of eight classes which each class consisted of 30 students. Therefore, the total number of population in this research was 240 students. The researcher used purposive sampling technique in determining class VIII A because based on the interview result with the English teacher at April 20th, 2016, the students' achievement in the regular evaluation result in the last semester was the lowest achievement score among the other classes. Therefore, the total number of sample in this research was 28 students. The researcher used the written test as the instrument of the research. The purpose of this test was to get data from the students' errors in constructing wh-questions. From this data, the researcher was able to know what kinds of error the students made. The test consisted of 12 items of translation and 12 items of transformation. In collecting the data, the researcher did some procedures below:

1. The researcher came to the class and met with the students who were going to be used as the sample.

2. The researcher explained what the students wanted to do as long as they were in the class.

3. The researcher distributed the test of wh-questions to the students.

4. The researcher explained how to do the test in 5 minutes.

5. The researcher asked the students to answer the test in 90 minutes.

6. The researcher collected the students' answer sheet and analyzed it. 
In analyzing the data, the researcher used the techniques below: The data was taken from test analysis that was conducted by arranging the data obtained systematically. This was done to make it more comfortable for the researcher to write the research report. The data gained from the test dealing with what kinds of errors the students did those in constructing wh-question. Percentage.

\section{Findings}

Based on the findings of students' tests result, the researcher found that respondent 1 until respondent 28 do 6 types of errors; they are an omission, simple addition, archi-form, alternating-form, misordering, and misselection. Besides, it can also be seen that the most errors are made by respondent 11 because he makes 60 errors in making wh-questions. Meanwhile, the least errors are made by respondent 7 because he makes 19 errors in arranging wh-questions. More detail about the result of calculating data of the students' errors in making wh-questions, it can be seen in table 1:

Table 1. The frequency and rate percentage of the students' errors in making wh-questions

\begin{tabular}{lcc}
\multicolumn{1}{c}{ Types of Error } & Frequency & Percentage \\
& $475)$ & 46.7 \\
\hline OOmission & 0 & 0 \\
D Double marking of addition & 0 & 0 \\
regularization of addition & 155 & 15.2 \\
simple addition & 0 & 0 \\
R Regularization of misformation & 275 & 28 \\
An Archi-form of misformation & 11 & 1.1 \\
$\begin{array}{l}\text { an alternating form of } \\
\text { misformation }\end{array}$ & 93 & 9.1 \\
M Misordering & 8 & 0.8 \\
M Deselection & 1017 & 100 \\
\hline$\quad$ Total & & \\
\hline
\end{tabular}

Table 1 describes the frequency and rate percentage of the students' errors in making wh-questions. It shows that there are 475 errors of omission with percentage is $46.7 \%$. There are no errors of double marking and regularization of addition, 155 errors of simple addition with percentage is $15.2 \%$, there are no errors of 
regularization of misformation, 275 errors of archi-form with percentage is $28 \%, 11$ errors of alternating form with percentage is 1.1\%, 93 errors of misordering with percentage is $9.1 \%$, and 8 errors of misselection with percentage is $0.8 \%$.

\section{Discussion}

There are some cases of language right as well as incomprehensible Based on the previous explanation in data description and data analysis in the findings, the second year students of SMP Negeri 2 Bua Ponrang have made different types of error in constructing wh-questions. Since each student has a different understanding of the question words which they have learned, therefore the students made different types in each tense. There are two kinds of test in this research is that translating whquestion from Indonesian into English and making wh-question based on the given answer.

Based on the findings in the previous part, there are 6 types of error that are done by the students in making wh-question, they are an omission, simple addition, archi-form, alternating-form, misordering, and misselection. Below are the descriptions of types of error made by the second year students of SMP Negeri 2 Bua Ponrang in making wh-questions in the simple present tense:

a. Omission

From 1017 of total errors, there were 475 errors of omission with percentage was $(46.7 \%)$. The most errors of omission that did by the students were the omission of helping verb and adjective. For examples:

Student 1. Error sentence: When ... you go?

Reconstruction: When do you go?

Student 2. Error sentence: Who is your ... friend?

Reconstruction: Who is your best friend?

Student 5. Error sentence: How ... your mother orders the ticket?

Reconstruction: How does your mother order the ticket?

Student 8. Error sentence: When ... her arrive in house?

Reconstruction: When does she arrive at home?

Concerning the discussion of students' omission error above, it relates to Dulay et all., (2010) theory that omission is characterized by the missing of an item that must appear in a well-structured utterance.

b. Simple Addition

From 1017 of total errors, there were 155 errors of simple addition with percentage was $15.2 \%$. A simple addition that made by the students when constructing wh-questions they added the, to, ing, $s$, etc. in their sentence. For examples:

Student 2. Error sentence: What color is your the bag?

Reconstruction: What color is your bag?

Student 9: Error sentence: Where do we go to ?

Reconstruction: Where do we go?

Student 18: Error sentence: Where do you fishing?

Reconstruction: Where do you fish? 
Student 20. Error sentence: What it is your hobby?

Reconstruction: What is your hobby?

Theoretically, the discussions of students' error of simple addition above, it was in line with the expert's idea that simple addition is characterized by the presence of linguistic item other than in a double marking or regularization (Dulay et al., 2010:138).

\section{c. Archi-form}

From 1017 of total errors, there were 275 errors of archi-form with percentage was $28 \%$. The most errors of archi-form that made by the students were archi-form of helping verb, question word, and personal pronoun of the subject. For examples:

Student 18. Error sentence: When is children practice the ballet?

Reconstruction: When do the children practice the ballet?

Student 1 . Error sentence: What is your favorite artist?

Reconstruction: Who is your favorite artist?

Student 3. Error sentence: Where do you live?

Reconstruction: Where do they live?

Based on the discussion of students' error of archi-form above, it was in line with the expert's idea that archi-form is characterized by the use of one member of a class of forms to represent others in the class (Dulay et al., 2010).

\section{d. Alternating form}

From 1017 of total errors, there were 11 errors of alternating form with percentage was $1.1 \%$. The most errors of alternating form that did by the students were confused in using a preposition. For examples:

Student 3. Error sentence: When it to arrive in house?

Reconstruction: When does it arrive at house?

Student 14: Error sentence: When her arrive in house?

Reconstruction: When does she arrive at house?

Student 18: Error sentence: When is arrive in home?

Reconstruction: When does he arrive at home?

The discussion above was in line with the expert's idea that alternating form is characterized by the use of a various member of a class with each other, it is caused by the development of the learner's vocabulary and grammar (Dulay et al., 2010).

e. Misordering

From 1017 of total errors, there were 93 errors of misordering with percentage was $9.1 \%$. Misordering is characterized by a morpheme or group of morphemes which are incorrectly placed in an utterance (Dulay et al., 2010). For example:

Student 12. Error sentence: Where your grandfather and grandmother do you live?

Reconstruction: Where do you grandfather and grandmother live?

Student 14. Error sentence: What is job your father?

Reconstruction: What is your father's job?

Student 15. Error sentence: When the do children practice the ballet?

Reconstruction: When do the children practice the ballet? 
Student 18. Error sentence: How do the happens accident?

Reconstruction: How does the accident happen?

\section{f. Misselection}

From 1017 of total errors, there were 8 errors of misselection with percentage was $0.8 \%$. The most errors of misselection that did by the students were misselection of the verb. James (2010) states that misselection is where the wrong item has been chosen in place of the right one. For Examples:

Student 1. Error sentence: When it come in home?

Reconstruction: When does it arrive at home?

Student 7. Error sentence: When it come in the house?

Reconstruction: When does it arrive at house?

Student 15.: Error sentence: When you go to the home?

Reconstruction: When does she arrive at home?

Referring to the types of error above, the type of errors that the students committed most was an omission of helping verb, and the least types of errors that the students committed were misselection of a verb. To be easier in comprehending the result of the research, the researcher presents the following bar chart:

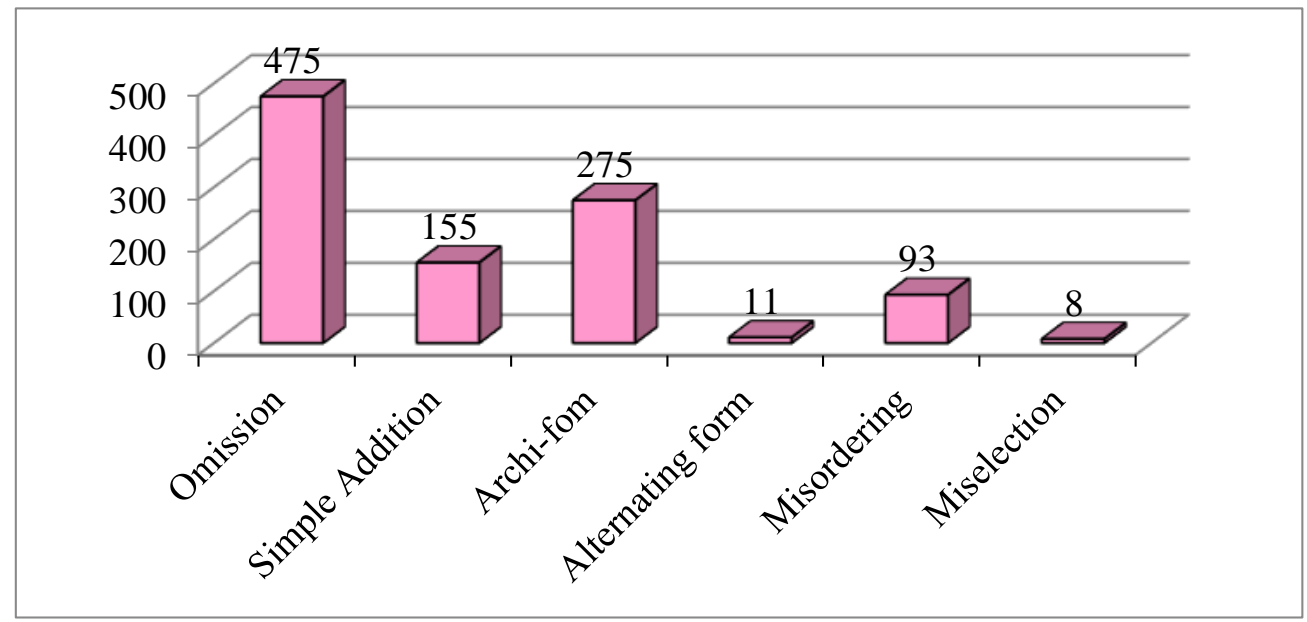

Figure 1. The frequency of students' errors in constructing wh-questions

Figure 1 shows the frequency students' errors in constructing wh-questions. It can be seen that there are 475 errors of omission, 155 errors of simple addition, 275 errors of archi-form, 11 errors of alternating form, 93 errors of misordering, and 8 errors of misselection. Therefore, it can be concluded that the most errors that made by the students were an omission, and the least errors were misselection.

Based on the result of data analysis, the researcher focused on the types of error by Dulay et al., (2010). According to this expert, there are four types of error; they are an omission, addition, misformation, and misordering. An addition is divided into three subtypes; they are double marking, regularization, and simple addition. Meanwhile, misformation is divided into three subtypes too; they are regularization, archi-form, and an alternating form. Besides the types of error by 
Dulay et al., the researcher also found the types of error by James (2010), it is misselection.

In analyzing the data, the researcher found 6 types of error; they are an omission, simple addition, archi-form, alternating-form, misordering, and misselection. Meanwhile, the students did not get the error of double marking, regularization of addition, and regularization of misformation, because they understood some rules in constructing wh-questions.

Based on the result of data analysis, it shows that the least error when the students arrange wh-questions is misselection. Misselection is an error that is caused by the wrong item has been chosen in place of the right one (James, 2010). The researcher can conclude that the reason for this error is that because the students have poor vocabulary and cannot choose the appropriate vocabulary based on the context of the sentence. Besides, the students do not understand the patterns comprehensively.

After misselection, there is alternating form as the second least error that is done by the students when making wh-questions. The alternating form is the error which is caused by the use of the various member of a class with each other (Dulay et al., 2010). The characteristic of this error is establishing a member of a class in an appropriate place but inappropriate in choosing the word of the class. Therefore, the researcher concludes that this error is caused by the student's grammar and structure still poor.

The most error that is done by the students is an omission. An omission is an error when the missing of an item that must appear in a well- structured utterance (Dulay et al., 2010). Generally, this error is caused by the students' misunderstanding of the structure of wh-questions. When making this error, the students always miss a word or some words when constructing wh-questions. This phenomenon also can be happened because of the students' weaknesses in remembering the vocabulary used in constructing the wh-questions. They sometimes forget the vocabulary used in the patterns; therefore, most of them make the omission errors. Most of the students at SMP Negeri 2 Bua Ponrang still need to improve their ability in mastering structure of the wh-questions.

\section{Conclusion}

Based on the research findings that explained in the previous chapter, the researcher concludes that the types of error that the second year students at SMP Negeri 2 Bua Ponrang committed to constructing wh-questions are an omission, simple addition, archi-form, alternating form, misordering, and misselection. The omission is dominant errors that the students made because from 1017 of total errors, 475 or $46.7 \%$ of the total errors are an omission. Then, it followed by archi-form with the total errors is 275 or $28 \%, 155$ errors of simple addition or $15.2 \%, 93$ errors of misordering or $9.1 \%, 11$ errors of alternating form or $1.1 \%$, and the least types of errors is misselection with 8 errors or $0.8 \%$. The limitation of this study is the number of the samples chosen and also the scope of the research is only limited on some selected wh-questions. Therefore, the researcher recommends to the nest researchers to research with a bigger number of sample and school to get more data about students' error analysis on wh-questions and also the next researcher can explore the all types of the wh-questions in English. Then, referring to the result of the research 
that the students' comprehension in constructing wh-question is still low, the next researchers are suggested to find method or strategy in improving the students' ability in constructing wh-questions.

\section{References}

Aboud, H. H. (2009). Error Analysis of the University Level Students in the Use of Concord. College of Education/Sammarra. 13/5: 277-283.

Azar, B. S. (2008). Fundamentals of English Grammar. Pearson Education, New York.

Aziz, S. S. (2011). Analysis of Errors in Paragraph Writing in English by Second Year Geography \& History Students at University of Baghdad. Journal of College Of Education for Women. 22/2: 371-387.

Brown, D. (2007). Principles of Language Learning and Teaching. Pearson, New York.

Bull, V. (2011). Fourth Edition. Oxford University Press, New York.

Casey, E. V. (2008). An Introduction to the Grammar of English. John Benjamins Publishing Company, Amsterdam.

Cotton, K. (2009). Classroom Questioning. North West Regional Educational Laboratory, Portland.

Cowan, R. (2008). The Teacher's Grammar of English: a Course Book and Reference Guide. Cambridge University Press, New York.

Dulay, H., Burt, M., and Krashen, S. (2010). Language Two. Oxford University Press, London.

Eastwood, J. (2007). Oxford Guide to English Grammar. Oxford University Press, London.

Ellis, R., and Barkhuzein, G. (2005). Analyzing Learner Language. Oxford University Press, London.

Erdogan, V. (2005). Contribution of Error Analysis to Foreign Language Teaching. Mersin University Journal of Faculty of Education. 1/2: 267-290.

Friedmann, N. (2010). Question Production in Agrammatism: the Tree Pruning Hypothesis. School of Education, Tel Aviv University, Tel Aviv 69978, Israel.

Gay, L. R. (2006). Educational Research Competence for Analysis and Application. Second Edition. Charles E. Pearson Meeril Publishing Company, USA.

Greenbaum, S. (2006). The Oxford English Grammar. Oxford University Press, London.

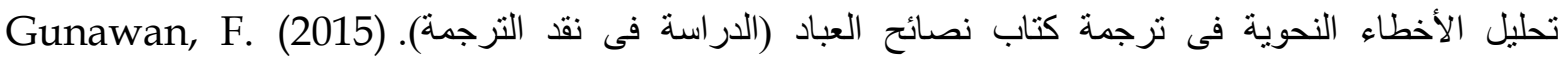
Langkawi: Journal of The Association for Arabic and English, 1(1), 71-84.

Gunning, T. G. (2010). Creating Literacy Instruction for All Children. Allyn and Bacon, Needham Height.

Harmer, J. (2007). The Practice of English Language Teaching. Longman, England.

Irfaniah, H. (2014). An Error Analysis in Making WH-Questions (A Case Study of the Second Year Students of SMP Islam Al-Syukro Universal. Unpublished Thesis. 
Jakarta: Faculty of Tarbiyah and Teachers Training. Syarif Hidayatullah State Islamic University.

James, C. (2010). Errors in Language Learning and Use: Exploring Error Analysis. Longman, London.

Kipfer, B. A. (Ed). (2009). Webster's College Dictionary. Random House, New York.

Kusumadewi, Hermariyanti (2017) Analysis of Students' Error in Constructing Nominal Clause. Wanastra Vol IX No. 2 September

Lester, M. (2008). ESL Grammar. McGraw-Hill, New York.

LeTourneau, M. S. (2010). English Grammar. Harcourt College Publishers, Orlando.

Masruddin. (2010). Error Analysis: A Teaching Book and Exercise. Palopo: LPS Press STAIN Palopo

Mendikoetxea, A. (2010). Focus on Errors: Learner Corpora as Pedagogical Tools. Continuum, London.

Richards, J. C. (2005). Dictionary of Language Teaching and Applied Linguistics. Longman, Essex.

Sari, M. P. (2013). An Analysis of Students' Errors in Constructing Wh-Questions Made by the Eighth Grade of SMPN 1 Gunung Jati. Unpublished Thesis. Cirebon: Faculty of Teaching and Education a Science. University of Swadaya Gunung Jati.

Strazny, P. (2005). Encyclopedia of Linguistics. Vol. 2. Fitzory Dearborn, New York.

Zawahreh, F. (2012). Applied Error Analysis of Written Production of English Essays of Tenth Grade Students in Ajloun Schools, Jordan. International Journal of Learning and Development. 2/2: 287-297. 